\title{
Cryptosporidiosis in Humans with Reference to the First Case of Cryptosporidium hominis Infection in Turkey
}

\section{Türkiye'de Illk Cryptosporidium hominis Enfeksiyonu Olgusuna Illişkin Olarak insanlarda Cryptosporidiosis}

\author{
Nadim Yılmazer, Şadiye Kaplan Küçük**, Gürkan Akyıldız, Ayşen Gargılı*, Sırrı Kar \\ Namık Kemal University Faculty of Arts and Sciences, Department of Biology, Tekirdağ, Turkey \\ * Marmara University Faculty of Health Sciences, Department of Nursing, Istanbul, Turkey \\ **Tekirdağ State Hospital, Microbiology Laboratory, Tekirdağ, Turkey
}

\section{Abstract}

Aim: Cryptosporidiosis is a worldwide zoonosis. Microscopic examinations may fail due to indistinctive morphological peculiarities of causative species. Hence, molecular diagnostics has become more important.

Methods: Stool samples from 150 patients were examined using carbol-fuchsin stain to determine Cryptosporidium spp. oocysts. Combined nested polymerase chain reaction-restriction fragment length polymorphism (PCR-RFLP) technique was used for establishing different species in positive samples. The samples were also screened for other parasites by wet-mount and zinc sulfate flotation methods.

Results: Microscopic examinations and molecular techniques revealed $0.67 \%(1 / 150)$ and $8.93 \%$ (5/56) positivity, respectively. Nested PCRRFLP enabled the detection of Cryptosporidium hominis (C. hominis) in one sample, while Cryptosporidium parvum (C. parvum) was detected in four samples. With this study, C. hominis was reported from humans for the first time in Turkey. Among infected ones, three of which were children, four patients excreted C. parvum oocysts had gastroenteritis, and a patient positive for $\mathrm{C}$. hominis had gastroenteritis accompanied by nausea and vomiting. No Giardia spp. and Entamoeba spp. were detected in all infected individuals.

Conclusion: C. parvum cases outnumbered C. hominis cases, suggesting a zoonotic transmission although infected individuals were living in an urban area where animal husbandry was not allowed. However, water-borne pathogen contamination in the city's water supply is considered a factor for transmission.

Keywords: Cryptosporidiosis, human, Turkey, polymerase chain reaction-restriction fragment length polymorphism
Öz

Amaç: Cryptosporidiosis dünya çapında bir zoonozdur. Mikroskopik muayene, etken türlerin belirgin olmayan morfolojik özellikleri nedeniyle başarısız olabilir. Bu nedenle moleküler tanı daha da önem kazanmıştır.

Yöntemler: Cryptosporidium spp. oosistlerini belirlemek için 150 hastanın dışkı örnekleri karbol-fuksin boya kullanılarak incelendi. Pozitif örneklerde farklı türlerin belirlenmesi için nested polimeraz zincir reaksiyonu-restriksiyon parça uzunluk polimorfizmi (PZR-RPUP) kullanıldı. Örnekler, diğer parazitler için yaş preparasyon ve çinko sülfat flotasyonu yöntemleriyle de araştıııldı.

Bulgular: Mikroskobik muayene ve moleküler yöntemlerle sırasıyla \%0,67 (1/150) ve \%8,93 (5/56) pozitiflik saptandı. Nested PZR-RPUP bir örnekte Cryptosporidium hominis'in (C. hominis), dört örnekte ise Cryptosporidium parvum'un (C. parvum) saptanmasına olanak verdi. Bu çalışma ile C. hominis Türkiye'de ilk kez insanlarda bildirildi. Enfekte olanlar arasında üçü çocuktu, dışkısında C. parvum oosistleri görülen dört hastada gastroenterit, C. hominis pozitif olan bir hastada ise mide bulantısı ve kusmanın eşlik ettiği gastroenterit vardı. Enfekte kişilerin hiçbirinde Giardia spp. ve Entamoeba spp. saptanmadı.

Sonuç: C. parvum olgularının C. hominis olgularından fazla olması, enfekte kişilerin hayvancılık yapılmasına izin verilmeyen kentsel alanda yaşamasına rağmen, bir zoonotik bulaşma olduğunu düşündürmektedir. Bununla birlikte, şehir suyundaki su kaynaklı patojen kirliliği bir bulaşma faktörü olarak düşünülmektedir.

Anahtar Sözcükler: Cryptosporidiosis, insan, Türkiye, polimeraz zincir reaksiyonu-restriksiyon parça uzunluk polimorfizmi
Address for Correspondence/Yazışma Adresi: Nadim Yılmazer

Namık Kemal University, Faculty of Arts and Sciences, Department of Biology, Tekirdağ, Turkey Phone: +90282 2502630 E-mail: nyilmazer@nku.edu.tr

Received/Geliş Tarihi: 09 January 2017 Accepted/Kabul Tarihi: 03 February 2017
${ }^{\circ}$ Copyright 2017 by The Medical Bulletin of University of Health Sciences Haseki Training and Research Hospital
The Medical Bulletin of Haseki published by Galenos Yayinevi.

${ }^{8}$ Telif Hakkı 2017 Sağlık Bilimleri Üniversitesi Haseki Eğitim ve Araştırma Hastanes Haseki Tıp Bülteni, Galenos Yayınevi tarafından basıımıştır. 


\section{Introduction}

Cryptosporidiosis is a worldwide zoonotic infectious disease caused by Cryptosporidium species. Infection may occur in avian, reptilian, fish and amphibian species along with 150 mammalian species including humans. Serious and life-threatening diarrhea can be resulted from this infection, especially in children and immunosuppressive adults $(1,2)$.

The agent of the disease is mainly transmitted by the fecal-oral route. Transmission may also occur with ingestion of water or food contaminated with oocysts, the infectious stage of Cryptosporidium, which are infective when shed with the feces of an infected host. A limited number of oocysts may establish an infection in a new host (1). Up to the present, around 30 species and more than 40 genotypes have been reported from various hosts, although validity of some species is controversial (3). On the other hand, 19 species are considered valid according to morphological characteristics and molecular analyses (2).

Different species or genotypes may reveal different clinical presentations and prognoses in the same host type (4). A number of Cryptosporidium species have zoonotic potential and may circulate among various animal species. Confirmation of these parasites in hosts as well as water and food is important to reveal the transmission dynamics and control the infection. However, microscopic examinations may fail due to indistinctive morphological peculiarities of Cryptosporidium species, and, hence, molecular diagnostics has become more important (5).

The aim of this study was to determine Cryptodsporidium species which affect humans in the province of Tekirdag in the European part of Turkey, and to handle the cases on the basis of clinical features and basic environmental characteristics.

\section{Methods}

\section{Fecal Samples}

In the present study conducted in Tekirdag, the most populated city in European Turkey, fecal materials left after completion of all tests requested by physicians were used. A total of 150 single stool samples were collected from patients who applied to the State Hospital with the complaints of diarrhea and other related gastrointestinal symptoms during the year of 2011, and stored in clean and disposable plastic cups. Stool consistency and clinical findings of the selected patients were noted. Ninety patients were male and 60 were female, and the average age of the patients was 19.2 years (2 months-78 years).

\section{Microscopic Examination of Feces}

Carbol fuchsin staining method: This method was used to display oocyst existence of Cryptosporidium spp. in stool samples and performed according to the description of Heine (6). Briefly, $50 \mu \mathrm{l}$ of homogenized fresh sample was taken over a slide. Then, an equal amount of carbol fuchsin was added. The sample was mixed and then a thin smear was prepared and air dried. This smear was mounted with a drop of immersion oil and was examined for oocysts under a light microscope at x40 magnification.

Wet-mount and zinc sulfate flotation methods: Microscopic examination of wet-mount of the stools was performed on each fresh sample. The remaining stool samples were preserved in 1:1 ratio with $2.5 \%$ potassium dichromate $(\mathrm{w} / \mathrm{v})$, and stored at $4^{\circ} \mathrm{C}$ until examination with saturated zinc sulfate centrifugal flotation method (7). Using both methods, the existence of leukocytes, erythrocytes, cysts of Giardia spp. and Entamoeba spp. was screened to evaluate the possible relationship between these parameters and cryptosporidiosis.

\section{Nested Polymerase Chain Reaction-Restriction Fragment Length Polymorphism}

Of the 150 stools, 55 samples were chosen, which were more susceptible for cryptosporidiosis according to the clinical description of the patients, and macroscopic and microscopic examination of the stools. In addition, one sample which was positive by the carbol fuchsin staining method was included in this group.

DNA was extracted from 56 of 150 samples (including the positive sample detected by carbol fuchsin staining) by using QIAamp DNA stool kit (QIAGEN, Germany), as suggested by the manufacturer. Nested polymerase chain reaction (PCR) and the subsequent restriction fragment length polymorphism (RFLP) analysis were carried out according to the protocol described by Xiao and Ryan (3). Primary PCR amplification was performed with primers SSU-F2 (5-TTCTAGAGCTAATACATGCG-3) and SSU-R2 (5-CCCATTTCCTTCGAAACAGGA-3) amplifying a fragment of the SSU rRNA gene, which is about 1325-bp long. Primer sets of SSU-F3 (5-GGAAGGGTTGTATTTATTAGATAAAG-3) and SSU-R4 (5-CTCATAAGGTGCTGAAGGAGTA-3) which amplify a region of about 840 bp were used for the nested PCR. Cryptosporidium species were differentiated by RFLP analysis of the secondary PCR products with endonucleases Sspl (Promega, USA) and Vspl (Promega, USA). The restriction digests were run and visualized by ethidium bromide staining on a $2.5 \%$ agarose gel.

\section{Results}

In the study, microscopic examination enabled the detection of Cryptosporidium spp. in one stool $(0.67 \%$; 1/150), whereas combined nested PCR-RFLP technique revealed the presence of the parasite in five stools $(8.93 \%$; 5/56). According to the results of PCR-RFLP examination, 
four samples were identified as Cryptosporidium parvum (C. parvum) and the other one as Cryptosporidium hominis (C. hominis) (Figure 1).

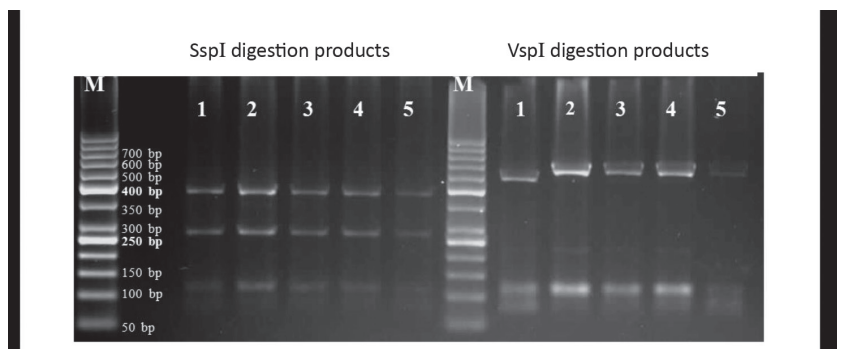

Figure 1. Electrophoretic separation of nested polymerase chain reaction-restriction fragment length polymorphism products of Cryptosporidium-SSU rRNA gene on $2.5 \%$ agarose gel for five positive samples (sample numbers are the same as in Table 1; Lane 1: C. hominis, Lanes 2-5: C. parvum, Lane M: 50 bp ladder). Nested polymerase chain reaction products of positive samples were digested with Vspl and Sspl. The expected fragments were: After Sspl digestion, 450, 267, 111, 12, and 11 bp for C. hominis, 450, 267, 108, 12, and 11 bp for C. parvum; after Vspl digestion, 561, 115, 104, and $71 \mathrm{bp}$ for C. hominis, 629, 115, and $104 \mathrm{bp}$ for $C$. parvum. The fragments smaller than $71 \mathrm{bp}$ are not visible in the gel

From the clinical evaluation of the patients, it was reported that four patients who excreted C. parvum oocysts had gastroenteritis while one patient positive for C. hominis had gastroenteritis accompanied by nausea and vomiting. In the fecal examination, neither Giardia spp. nor Entamoeba spp. cysts were detected. Furthermore, there were no leukocytes or erythrocytes on fecal microscopy of the patient infected with C. hominis. On the other hand, concerning C. parvum-positive feces, both leukocytes and erythrocytes were present in two samples, whereas only leukocytes were seen in one sample, and one sample lacked these cell types. Based on the causative species, some important clinical data of the patients are shown in Table 1.

\section{Discussion}

In previous studies, the prevalence of cryptosporidiosis was found to be between $0.4 \%$ and $35.5 \%$ in humans from different age groups and with different immune status in Turkey (8). It has been reported that the prevalence of cryptosporidiosis in humans and animals varied from country to country, and even among different regions of the same country. Differences between prevalence rates are related to the zoonotic nature of the disease, socioeconomical conditions, water and food contamination, and general hygiene conditions. Infection is more prevalent among children and in immunosuppressive adults $(1,9)$. In this study, three of five positive individuals were children.

Studies have revealed that a variety of animal species including cats and dogs (10) can serve as a source of zoonotic cryptosporidiosis, and calves are likely the most important source. Up to date, C. hominis, C. parvum, C. meleagridis, C. felis, C. canis, C. muris, C. suis, C. andersoni, and Cryptosporidium cervine genotype and chipmunk genotype have been reported from humans. It was shown that $C$. hominis and especially $C$. parvum are responsible for $90 \%$ of human cases worldwide and the rest of the cases are seen as sporadical $(2,3,11)$.

Human cryptosporidiosis caused by C. parvum mainly occurs in rural areas (12) and detection of the agent in persons with animal contact (10) refers to the zoonotic transmission $(13,14)$. In the present study, C. parvum cases outnumbered $C$. hominis cases, suggesting a zoonotic transmission. Although studies on the presence or prevalence of cryptosporidiosis in animals are as yet unavailable for the Thrace region, it is well known that cryptosporidiosis is endemic in animals (15-17) and present in humans (17-19) in Turkey. Animals harbour $C$. parvum (20), C. bovis and C. ryanae (21) in various parts of Turkey. On the other hand, five Cryptosporidium-positive individuals were living in an urban area where animal husbandry was not allowed. Consequently, contamination of the water supplies could be assigned as an issue. In fact, the risk of water contamination is higher during the

\begin{tabular}{|c|c|c|c|c|c|}
\hline Sample & Pathogen & $\begin{array}{l}\text { Age (year) and gender of } \\
\text { patients }\end{array}$ & $\begin{array}{l}\text { Sampling } \\
\text { month }\end{array}$ & $\begin{array}{l}\text { First clinical } \\
\text { symptoms }\end{array}$ & Microscopic examination \\
\hline 1 & C. hominis & 2; male & July & $\begin{array}{l}\text { Gastroenteritis, } \\
\text { nausea, vomiting }\end{array}$ & CF $(+)^{\#}$, Other parasites* (-), Leukocyte (-), Erythrocyte (-) \\
\hline 2 & C. parvum & 4; female & November & Gastroenteritis & CF $(-)^{\#}$, Other parasites* $(-)$, Leukocyte $(+)$, Erythrocyte $(+)$ \\
\hline 3 & C. parvum & 21; female & June & Gastroenteritis & CF $(-)^{\#}$, Other parasites* $(-)$, Leukocyte $(+)$, Erythrocyte $(+)$ \\
\hline 4 & C. parvum & 37; male & July & Gastroenteritis & CF $(-)^{\#}$, Other parasites* $(-)$, Leukocyte $(+)$, Erythrocyte $(-)$ \\
\hline 5 & C. parvum & 5; male & July & Gastroenteritis & CF (-)\#, Other parasites* $(-)$, Leukocyte $(-)$, Erythrocyte $(-)$ \\
\hline \multicolumn{6}{|c|}{$\begin{array}{l}\text { CF: Carbol fuchsin staining } \\
{ }^{*} \text { Giardia spp. and Entamoeba spp. cysts } \\
\text { \#Existence of Cryptosporidium spp. oocysts by carbol fuchsin staining }\end{array}$} \\
\hline
\end{tabular}


rainy season (3), however four cases were seen in June and July. In addition, the patients were living in different localities of the city, hence excluding the possibility of a local water contamination. Recently, molecular analyses revealed that C. parvum has genetically distinct subtypes/ subgenotypes in humans and cattle, and a number of these subgenotypes are specific to humans, and some of them show anthropogenic transmission whereas others are zoonotic $(3,22)$. Thus, these subgenotypes can contribute to an explanation of C. parvum infections in humans with no animal contact. Herein, synanthropic rodents are a factor that we may take into consideration since transmission of Cryptosporidium tyzzeri and C. parvum from wild mice to humans can occur as demonstrated in a case by Rašková et al. (23).

C. parvum is the most common in the Middle East, and the prevalence varies between countries and regions. C. hominis has been reported to be more prevalent in Netherlands (12) and Egypt (14), whereas C. parvum in Ireland (24), Ethiopia (13) and Iran (25). The prevalence of the species reported here is similar to that in the UK (9). In the USA, C. hominis is responsible for the majority of cryptosporidiosis outbreaks, and zoonotic species have been reported from sporadic cases $(26,27)$. In Turkey, $C$. parvum and C. meleagridis (28) have been reported from humans. The present study reported C. parvum (in four samples) and C. hominis (in one sample) from five positive samples, and C. hominis was encountered in the country for the first time. However, it is noteworthy that this species was encountered in a person in England, who returned from a travel to Turkey (29). Although cryptosporidiosis is generally characterized by homogeneous, yellowish and aqueous diarrhea (1), different species or genotypes may lead to different clinical manifestations and prognoses in the same host type $(3,27)$. Clinical table of the disease may vary from subclinical form to life-threatening diarrhea, depending on factors such as age and immune status of the patient (30). C. hominis, which is associated with a longer duration of symptoms and oocyst shedding, leads to more severe clinical features in humans rather than C. parvum. Additionally, C. hominis infections have been reported to be seen in children, while $C$. parvum affects adults $(12,31,32)$. It has also been presented that clinical and pathological characteristics can vary depending on the subtypes of the agent, and some $C$. hominis subtypes, such as subtype Ib identified by GP60 sequence, may cause severe diarrhea accompanied by vomiting and malaise $(3,27)$. These clinical diversities were encountered in the patients in the present study. These results indicate that in spite of the variety of the factors affecting clinical characteristics of cryptosporidiosis, definition of these factors could be helpful for the diagnosis of the disease and prediction of the agent at the species level.

\section{Conclusion}

This study has important implications for understanding the transmission dynamics of Cryptosporidium spp. which affect humans in Thrace, the European part of Turkey, an important area for transmission of diseases from Asia to Europe or vice versa. The study reports the first occurrence of human C. hominis infection from Turkey. The outcome of our study will be crucial to better reveal the epidemiology and transmission of cryptosporidiosis in our country, and also to bring highlights to the clinical evaluation of this disease. Higher rate of C. parvum among the positive samples suggests a zoonotic transmission, although infected individuals were living in an urban area. However, sources of contamination other than animal contact, such as the contamination of the water supplies, should be taken into consideration.

\section{Ethics}

Ethics Committee Approval: It was not taken.

Informed Consent: It was taken.

Peer-review: Externally and internally peer-reviewed.

\section{Authorship Contributions}

Concept and Design: S.K., S..K.K., N.Y. Data Collection or Processing: S..K.K., G.A. Analysis or Interpretation: S.K., A.G. Literature Search: N.Y., S.K. Writing: N.Y., S.K., A.G.

Conflict of Interest: No conflict of interest was declared by the authors.

Financial Disclosure: The authors declared that this study received no financial support.

\section{References}

1. Sears $C L$, Kirckpatrick BD. Cryptosporidiosis and isosporiosis. In: Gillespie SH, Pearson RD, editors. Principles and Practice of Clinical Parasitology. 1st ed. UK: John Wiley \& Sons Ltd. Press; 2001. p. 139-64.

2. Fayer R. Taxonomy and species delimitation in Cryptosporidium. Exp Parasitol 2010;124:90-7.

3. Xiao L, Ryan UM. Molecular epidemiology. In: Fayer R, Xiao L, editors. Cryptosporidium and Cryptosporidiosis. 1st ed. Boca Raton: CRC Press; 2008. p. 119-72.

4. Xiao L. Molecular epidemiology of cryptosporidiosis: an update. Exp Parasitol 2009;124:80-9.

5. Jex AR, Smith HV, Monis PT, Campbell BE, Gasser RB. Cryptosporidium-biotechnological advances in the detection, diagnosis and analysis of genetic variation. Biotechnol Adv 2008;26:304-17.

6. Heine J. Eine einfache Nachweismethode für Kryptosporidien im Kot. Zbl Vet Med B 1982;29:324-7.

7. Truant $A L$, Elliott SH, Kelly MT, Smith JH. Comparison of formalin-ethyl ether sedimentation, formalin-ethyl acetate 
sedimentation, and zinc sulfate flotation techniques for detection of intestinal parasites. J Clin Microbiol 1981;13:882-4.

8. Uyar Y, Taylan Ozkan A. Antigen detection methods in diagnosis of amebiasis, giardiasis and cryptosporidiosis. Turkish Parazitol Derg 2009;33:140-50.

9. Nichols G. Epidemiology. In: Fayer R, Xiao L, editors. Cryptosporidium and Cryptosporidiosis. 1st ed. Boca Raton: CRC Press; 2008. p. 79-118.

10. Stantic-Pavlinic M, Xiao L, Glaberman S, et al. Cryptosporidiosis associated with animal contacts. Wien Klin Wochenschr 2003;115:125-7.

11. Coklin T, Uehlinger FD, Farber JM, Barkema HW, O'Handley RM, Dixon BR. Prevalence and molecular characterization of Cryptosporidium spp. in dairy calves from 11 farms in Prince Edward Island, Canada. Vet Parasitol 2009;160:323-6.

12. Wielinga PR, de Vries A, van der Goot TH, et al. Molecular epidemiology of Cryptosporidium in humans and cattle in The Netherlands. Int J Parasitol 2007;38:809-17.

13. Adamu H, Petros B, Hailu A, Petry F. Molecular characterization of Cryptosporidium isolates from humans in Ethiopia. Acta Trop 2010;115:77-83.

14. Abd El Kader NM, Blanco MA, Ali-Tammam M, et al. Detection of Cryptosporidium parvum and Cryptosporidium hominis in human patients in Cairo, Egypt. Parasitol Res 2012;110:1616.

15. Sarı B, Aktaş MS, Arslam MÖ. Erzurum yöresinde buzağılarda Cryptosporidium türlerinin prevalansı. Türkiye Parazitol Derg 2008;32:116-9.

16. Gül A, Çiçek M, Kılınç Ö. Van yöresi buzağılarında Eimeria spp., Cryptosporidium spp. ve Giardia spp.'nin yaygınlığı. Türkiye Parazitol Derg 2008;32:202-4.

17. Çiçek M, Körkoca H, Gül A. Van belediye mezbahasında çalışan işçilerde ve kesimi yapılan hayvanlarda Cryptosporidium spp.'nin araştırılması. Türkiye Parazitol Derg 2008;32:8-11.

18. Otağ F, Aslan G, Emekdaş G, Aydın E, Ök AT, Çeber K. Mersin ilinde ilkokul öğrencilerinde Cryptosporidium spp. ookistlerinin araştırılması. Türkiye Parazitol Derg 2007;31:17-9.

19. Tamer GS, Balıkçı E, Erbay A. Lösemi ve lenfoma tanısı alan çocuklarda cryptosporidiosis prevalansı. Türkiye Parazitol Derg 2008;32:192-7.

20. Arslan MO, Itik-Ekinci A. Determination of Cryptosporidium parvum subtypes in cattle in Kars province of Turkey. Kafkas Univ Vet Fak Derg 2012;18(Suppl-A):221-6.
21. Şimsek AT, İnci $A$, Yıldırım A, Çiloğlu A, Bişkin Z, Düzlü Ö. Nevşehir yöresinde ishalli buzağılarda Cryptosporidium türlerinin moleküler prevalansı ve karakterizasyonu. 17. Ulusal Parazitoloji Kongresi ve Kafkasya ve Ortadoğu Paraziter Hastalıklar Sempozyumu; 4-10 Eylül 2011; Kars, Türkiye. Türkiye Parazitoloji Derneği; 2011. p. 158-9.

22. Widmer G, Sullivan S. Genomics and population biology of Cryptosporidium species. Parasite Immunol 2012;34:61-71.

23. Rašková $V$, Kvetonová $D$, Sak $B$, et al. Human cryptosporidiosis caused by Cryptosporidium tyzzeri and C. parvum isolates presumably transmitted from wild mice. J Clin Microbiol 2013;51:360-2.

24. Zintl $A$, Proctor $A F$, Read $C$, et al.The prevalence of Cryptosporidium species and subtypes in human faecal samples in Ireland. Epidemiol Infect 2009;137:270-7.

25. Nazemalhosseini-Mojarad E, Haghighi A, Taghipour N, et al. Subtype analysis of Cryptosporidium parvum and Cryptosporidium hominis isolates from humans and cattle in Iran. Vet Parasitol 2011;179:250-2.

26. Feltus DC, Giddings CW, Schneck BL, Monson T, Warshauer D, McEvoy JM. Evidence supporting zoonotic transmission of Cryptosporidium spp. in Wisconsin. J Clin Microbiol 2006;44:4303-8.

27. Cama VA, Ross JM, Crawford S, et al. Differences in clinical manifestations among Cryptosporidium species and subtypes in HIV-infected persons. J Infect Dis 2007;196:684-91.

28. Usluca S, Aksoy U. Detection and genotyping of Cryptosporidium spp. in diarrheic stools by PCR/RFLP analyses. Turk J Med Sci 2011;41:1029-36.

29. Chalmers RM, Hadfield SJ, Jackson CJ, Elwin K, Xiao L, Hunter P. Geographic linkage and variation in Cryptosporidium hominis. Emerg Infect Dis 2008;14:496-8.

30. Warren CA, Guerrant RL. Clinical disease and pathology. In: Fayer R, Xiao $L$, editors. Cryptosporidium and Cryptosporidiosis. 1st ed. Boca Raton: CRC Press; 2008. p. 235-54.

31. Guk SM, Yong TS, Park SJ, Park JH, Chai JY. Genotype and animal infectivity of a human isolate of Cryptosporidium parvum in the Republic of Korea. Korean J Parasitol 2004;42:85-9.

32. Bushen OY, Kohli A, Pinkerton RC, et al. Heavy cryptosporidial infections in children in northeast Brazil: comparison of Cryptosporidium hominis and Cryptosporidium parvum. Trans R Soc Trop Med Hyg 2007;101:278-84. 